\title{
Contact Stress In Helical Bevel Gears
}

Edward E. Osakue

Department of Industrial Technology Texas Southern University Houston, Texas,

USA

Lucky Anetor Department of Engineering Texas Southern University Houston, Texas,

USA

Kendall Harris
Provost \& Vice President for
Academic Affairs
Texas Southern University
Houston, Texas,

USA
Helical bevel gears have inclined or twisted teeth on a conical surface and the common types are skew, spiral, zerol, and hypoid bevel gears. However, this study does not include hypoid bevel gears. Due to the geometric complexities of bevel gears, commonly used methods in their design are based on the concept of equivalent or virtual spur gear. The approach in this paper is based on the following assumptions, a) the helix angle of helical bevel gears is equal to mean spiral angle, b) the pitch diameter at the backend is defined as that of a helical gear, and c) the Tredgold's approximation is applied to the helical gear. Upon these premises, the contact stress capacity of helical bevel gears is formulated in explicit design parameters. The new contact stress capacity model is used to estimate the contact stress in three gear systems for three application examples and compared with previous solutions. Differences between the new estimated results and the previous solutions vary from $-3 \%$ and $-11 \%$, with the new estimates being consistently but marginally or slightly lower than the previous solution values. Though the differences appear to be small, they are significant because the durability of gears is strongly influenced by the contact stress. For example, a 5\% reduction in contact stress may result in almost $50 \%$ increase in durability in some steel materials. The equations developed do not apply to bevel crown gears.

\section{Keywords: Gears, Contact stress, Fatigue, Helix angle, Equivalent spur gear}

\section{INTRODUCTION}

The term "helical bevel gear" is used in this paper to describe bevel gears that have inclined or twisted teeth on a conical surface. The common types are skew, spiral, zerol, and hypoid bevel gears, but hypoid gears are excluded from the current study. Fig. 1 shows the schematic diagrams of skew, zerol and spiral gears. Skew bevel gears (Fig. 1a) have a constant spiral angle like helical cylindrical gears. The helix angle of zerol or spiral bevel gears is defined as the mean spiral angle at the face mid-width of the gears and it is the curvature of the tooth at that point as indicated in Fig. 1c. Practically, the spiral angle varies from the frontend (toe) to the backend (heel) of the gear. Because of the curved shape of the tooth length of zerol and spiral bevel gears, different points along the face width have different spiral angles [1]. Zerol and spiral bevel gears have variable spiral angle but the helix angle for zerol bevel gears is zero degree. Though spiral bevel gears resemble helical gears, they however, do not have a true helical spiral $[2,3]$. A bevel gear frustum may be construed as a series of step disks with cylinder diameters that vary from the front end to the back end. The mid-section disk is where the forces are acting. The mean spiral angle of the bevel gear corresponds to the nominal helix angle of the mid-section disk. The International

Standardization Organization (ISO) recommends a pressure angle of $20^{\circ}$ for bevel gears, which is the most popular pressure angle in North America. However, other pressure angles like $14.5^{\circ}, 22.5^{\circ}$ and $25^{\circ}$ are in use.

Received: May 2021, Accepted: June 2021

Correspondence to: Prof. Edward E. Osakue,

Department of Industrial Technologies, Texas

Southern University Houston, Texas, USA

Email: edward.osakue@tsu.edu

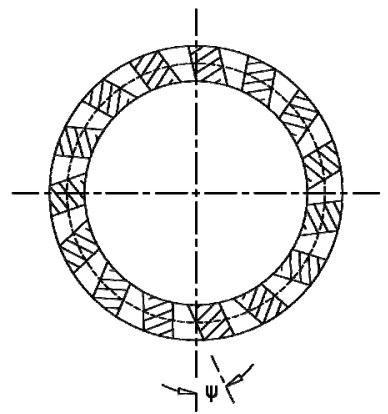

a) Skew

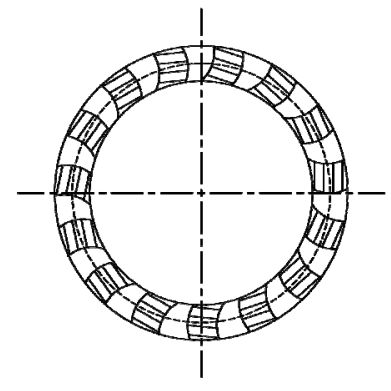

b) Zerol

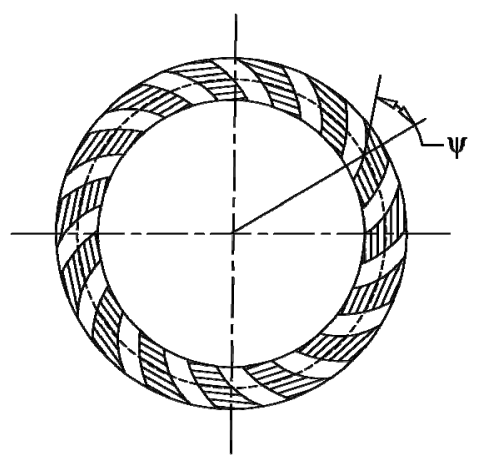

c) Spiral

\section{Fig. 1: Types of helical bevel gears}

Zerol bevel gears (Fig. 1b) are similar to the straight bevel gears and may carry slightly higher load rating. They can be used instead of straight bevels without mounting changes but can run as fast as spiral bevel gears. Zerol bevels are widely employed in the aircraft industry, where precision gears are generally required. Spiral bevel gears (Fig. 1c) are recommended for use where high speed (usually above $5 \mathrm{~m} / \mathrm{s}$ ) are encountered. Unground spiral bevel gears can be used up to $11 \mathrm{~m} / \mathrm{s}$ and ground gears up to $61 \mathrm{~m} / \mathrm{s}$. Higher speeds need 
precision-finished gears which may be used up to 125 $\mathrm{m} / \mathrm{s}$ [4-7].

The gear ratio in helical gearsets is generally more than 3. Single stage gear ratio of 10 is about the maximum for speed reducers and the maximum gear ratio for single stage speed increasers is about $5[8,9]$. The pinion should have a minimum of 12 teeth in the gearsets. The helix angle of the pinion and gears is the same for spiral bevel gears and the most common helix angle is $35^{\circ}$ [8] but helix angles of $20^{\circ}$ to $45^{\circ}$ may be used with the same tooth proportions as for $35^{\circ}$ [10]. The helix angle allows multiple teeth to overlap facially if the facewidth is sufficiently large. The face contact ratio is the ratio of the face advance to the circular pitch. Higher helix angles give higher face contact ratio, smoother and quieter operations but increase axial loads on shafts, bearings and housing. For smooth spiral tooth action, the face contact ratio should be more than 1.25. However, maximum smoothness of drive is attained when the face contact ratio is between 1.5 and 2.0 [10, 11]. High speed applications should be designed with a face contact ratio of 2 or higher [11]. The hand of the helix for spiral bevel gears may be left or right. The hand should be chosen so that the gears separate from each other during rotation to avoid jamming [12].

The teeth of helical bevel gears can tolerate small amounts of misalignment in the assembly of the gears and some displacement of the gears under load without concentrating the tooth contact at the ends of the teeth [4]. Generally, spiral bevel gears are capable of carrying more load than straight-bevel gears because of better load sharing from the spiral angle and are used for high speed and high power transmission [7].

According to Feng and Song [13], spiral bevel gears have very complex tooth geometries and kinematics. Unlike cylindrical gears, the mesh point, mesh force, and line-of-action vector for spiral bevel gears are time varying quantities in $3 \mathrm{D}$ space. They are more difficult to design and costly to manufacture because they require specialized and sophisticated machinery. Both spiral and zerol gears can be cut on the same machines with the same circular face-mill cutters or ground on the same grinding machines. When cutting zerol bevel gears the mean spiral angle is set to zero [2].

Bevel gears are usually carburized to a surface hardness in the range of $700 \mathrm{HVN}$ to $770 \mathrm{HVN}$ (60 to $63 \mathrm{HRC}$ ) with the pinion hardness about $30 \mathrm{HVN}$ (3 RHC) higher to equalize wear and minimize risk of scoring. The core hardness is in the range of $300 \mathrm{HVN}$ to $400 \mathrm{HVN}$ (30 to $40 \mathrm{HRC)} \mathrm{[1].} \mathrm{Distortion} \mathrm{is}$ experienced after hardening and hard finishing is done to correct this. Face run-out is a problem with bevel ring gears. The manufacturing dimensions of a bevel gear are based on the bevel gear backend module which is largely standardized. When addendum modification is used in bevel and hypoid gears, usually the pinion and gears have the same shift coefficient values but opposite algebraically, so that the residual sum of the coefficients is zero [14].

For the most part, the geometry of spiral-bevel gears is extremely complex and that makes their design calculations more complicated and empirical compared to cylindrical gears but the underlying concepts are the same $[15,6]$. ANSI/AGMA 2003-B97 [16] is a popular bevel gear design standard in the United States and provides a conservative means of estimating the contact and bending stresses in straight, zero, and spiral bevel gears [8)]. According to Dudley [2], stresses estimated using the general practice developed in the U.S. for bevel gears predict quick failure but such gears are known to be satisfactory in service. According to him "This is a serious problem." In this article we explore the possibility of formulating a contact stress capacity model for helical bevel gears that is less conservative than the AGMA model. The objective of this research work was to explore the possibility of formulating a less conservative bevel gear contact stress model than current available gear standards in the U.S. or elsewhere. This will allow more accurate estimation of contact stress in bevel gears that can predict longer durability. Also, developing relatively accurate simplified design analysis methods help to shorten design and development times and thus reduce design project costs. The efforts in such an endeavor resulted in the model that is presented in this article. The power loss per mesh in bevel gear drives is of the order of $2 \%$ [17] which is considered negligible in this study.

\section{EQUIVALENT SPUR GEAR FOR HELICAL BEVEL GEARS}

The forces acting on bevel gears are three dimensional and are discussed in the Appendix. The complexities $[15,18]$ of the geometry of bevel gears in general and those of helical bevel gears in particular, do not permit simple mathematical analysis. Therefore, approxi-mations are made to allow more simplified analysis which gives rise to equivalent spur gears. The development of an equivalent or a virtual spur gear for a helical bevel gear is based on two assumptions: helical cylindrical gear analogy and Tredgold's approximation. This approach results in a bi-equivalent spur gear which is explained below.

\subsection{Helical Gear Analogy}

Cylindrical gears have pitch circles on a cylinder and a constant helix angle. The common planes associated with them are the axial, transverse and normal planes. The transverse plane is the plane of rotation and is perpendicular to the axial direction. The gear diameter is shown in the transverse or diametral plane while the gear width is shown in the axial plane. Spur gears are defined only by the axial and transverse plane but helical gears have a normal plane in addition to those for spur gears because the gear tooth profile is often defined in the normal plane. The normal plane intercepts the pitch cylinders so that the gear tooth profile generated on it has the same properties as the actual helical gear. As in spur gears, the driving force for helical gearsets lies in the transverse plane but actual contact of gear teeth is commonly believed to occur in the normal plane. The two parameters which relate a helical gear to its equivalent spur gear are the transverse pressure angle and the base helix angle [19]. When the normal pressure angle is standardized, then: 


$$
\phi_{t}=\tan ^{-1}\left[\frac{\tan \phi_{n}}{\cos \psi}\right] \psi_{b}=\tan ^{-1}\left[\tan \psi \cos \phi_{t}\right]
$$

Please observe that there are two (2) sub-equations in Eq. (1), which should be referred to as Eq. (1a) and Eq. (1b) from left to right. All other equations with multiple terms should be interpreted similarly. Reference should be made to Nomenclature for the definition of parameters in equations in Eq. (1) and others.

According to Maitra [10], the base helix angle gives a more accurate estimate of the instantaneous radius of curvature of the equivalent spur gear for a helical gear. Therefore, the plane defined by the base helix angle will be called the virtual plane on which the pitch diameter of the virtual spur gear for a helical gear lies. Consequently, the base helix angle becomes a significant parameter in gear design analysis as it defines the plane of contact for the meshing gear teeth. Because the difference in values for the nominal and base helix angles is small in most cases, a small error is incurred when the nominal helix angle is used instead of the base helix angle in design analysis. Since the virtual and normal planes are different, the gears associated with them need to be differentiated. Conceptually, the following gears may be distinguished by their pitch circle diameters for clarity of discussions. They are the nominal spur gear, helical gear, backend spur gear, the heli-spur gear, and the bevi-spur gear.

The pitch diameters of the nominal spur gear and that of the helical gear are given by Eq. (2a) and Eq.(2b), respectively.

$$
d_{o}=m_{n} z \quad d=\frac{d_{o}}{\cos \psi}
$$

The backend spur gear of a bevel gear is conventionally treated as a spur gear by using Eq. (3a). As can be observed, the transverse module of the backend spur gear is determined from Eq. (3b) in the present study. This makes the approach adopted different from conventional practice because the backed spur gear is being treated as a helical gear.

$$
d_{e}=m_{e} z m_{e}=\frac{m_{n}}{\cos \psi} \mu=\frac{d_{e 2}}{d_{e 1}}=\frac{z_{2}}{z_{1}}
$$

It is important to note that the backend spur gear has no real defined facewidth. In Eq. (3c) and others like it, subscript 1 is used for the pinion and subscript 2 is used for the gear.

Heli-spur gear is used to describe the virtual or equivalent spur gear for a helical gear and the bevi-spur gear is used to describe the virtual or equivalent spur gear for a bevel gear. For a straight bevel gear where the nominal helix angle is zero and the bevi-spur gear can be rightly called the Tredgold's spur gear.

Fig. 2 shows the graphical development of the pitch circles of the heli-spur gear and the bevi-spur gear. Fig. $2 a$ shows the nominal spur gear and Fig. $2 b$ shows the helical gear. Fig. 2b graphically illustrates how the helical gear pitch diameter is developed from the pitch diameter of the nominal spur gear. Fig. 2c indicates the pitch circle diameters of the heli-spur and bevi-spur gears. Also, it graphically demonstrates how the pitch circle diameters of these virtual spur gears are developed from that of the nominal spur gear.

The heli-spur gear has an instantaneous pitch diameter that is a function of the base helix angle $\left(\psi_{b}\right)$ [10] of the helical gear. The pitch radius of the heli-spur gear is shown in Fig. 2c and is represented by the $\mathrm{O}^{\prime} \mathrm{B}$ which is defined in Eq. (4)[19].

$$
d_{n}=\frac{d_{o}}{\cos ^{2} \psi_{b}}=\frac{m_{n} z}{\cos ^{2} \psi_{b}}=\frac{d \cos \psi}{\cos ^{2} \psi_{b}}
$$

The heli-spur gear is associated with the base helix angle, not the nominal helix angle because the plane defined by the base helix angle contains the instantaneous radius of curvature for the heli-spur gear. Therefore, the base pitch associated with the heli-spur gear should be defined on the plane of the base helix angle, not that of the nominal helix angle. Consequently, the number of teeth on the instantaneous diameter is approximately obtained as:

$$
z_{n} \approx \frac{\pi d_{n}}{\pi m_{n} \cos \psi_{b}}=\frac{z}{\cos ^{2} \psi_{b}}
$$

It is to be noted that the virtual plane where the helispur gear is defined is clearly different and distinct from that of the normal angle. The normal plane is real or physical, but the virtual plane is fictitious and is derived from analytical calculus. Therefore, the heli-spur gear is not real, it is simply a geometrical construct. However, the applied load on the helical gear is transferred to the heli-spur gear which can be used to estimate the contact and root bending stresses on the heli-spur gear and thereby simulate the actual contact and root bending stresses on the physical helical gear.

\subsection{Tredgold's approximation}

Bevel gear teeth are cut on conical surfaces and have a spherical geometry; therefore, the involute tooth profile should be developed on a spherical surface to ensure conjugate action. Since the projection of bevel gear teeth on the surface of a sphere would indeed be a difficult and time-consuming problem, it is necessary practically, to approximate bevel gear tooth profile as accurately as possible. The "Tredgold's approximation" is almost universally accepted and it uses the cone tangent to the sphere at the pitch point on the backend of the bevel gear to define the pitch radius of an equivalent spur gear. The basic shape of a bevel gear tooth is almost the same as that of this spur gear. The Tredgold's approximation is accurate enough for practical purposes as long as the bevel gear has 8 or more teeth, [10, 15, 20, 21]. The Octoid tooth profile is often used for implementing the Tredgold's approximation. The technique allows easy manufacture [15] of bevel gears by the method of gear generation. The manufacturing dimensions of a bevel gear are based on the backend module, which is largely standardized. 


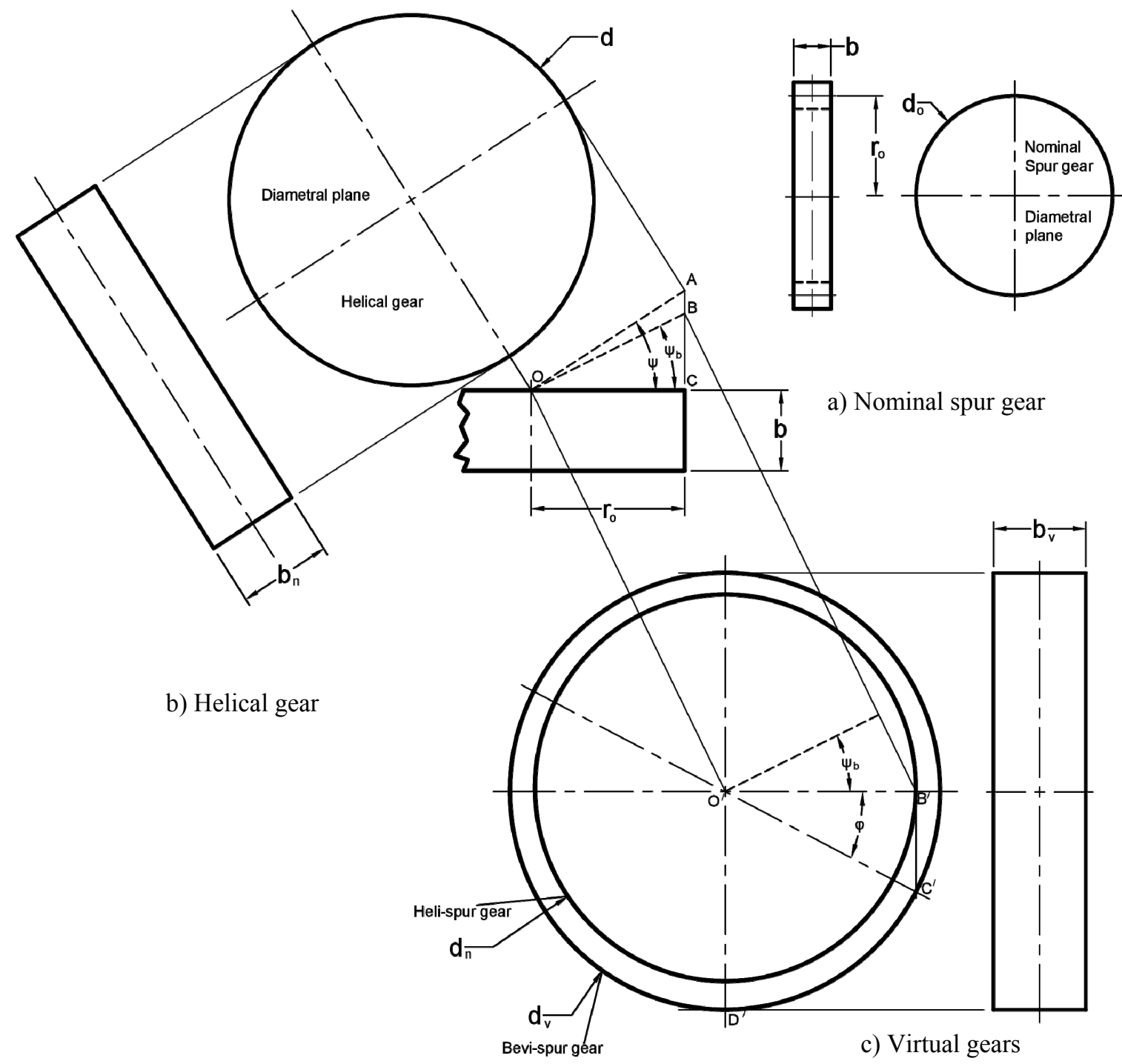

Figure 2: Graphical development of the pitch circle diameters of helical bevel gear

Assuming the Tredgold's approximation, an imaginary equivalent or bevi-spur gear may be prescribed whose pitch radius is equal to the backend cone radius of the helical gear $[10,15]$. From the previous discussions in helical gear analogy, the backend diameter of the bevi-spur gear is taken as that of a helical cylindrical gear. Therefore, the Tredgold's spur gear has the same module as this helical gear of Fig. 2b. Fig. $2 c$ shows the radius of the bevi-spur gear as length $\mathrm{O}^{\prime} \mathrm{C}^{\prime}$. It is to be noted in Fig. 2c that when the pitch angle of a bevel gear is large and tends toward $90^{\circ}$, the line $\mathrm{B}^{\prime} \mathrm{C}^{\prime}$ becomes excessively long so that the pitch diameter of the bevi-spur gear tends to infinity. This leads to a crown gear with a pitch angle of $90^{\circ}$ that may be likened to a circular rack. From Fig. 2c, the pitch diameter of the bevi-spur gear for a helical bevel gear is:

$$
d_{v}=\frac{d_{n}}{\cos \phi}=\frac{d \cos \psi}{\cos \phi \cos ^{2} \psi_{b}}
$$

In the present consideration, the Tredgold's approximation converts the helical gear into the bevi-spur gear for helical bevel gear. Helical bevel gears are then analogous to helical cylindrical gears but with the pitch cylinder on a cone and a variable helix angle. The base helix angle of the helical bevel gear is obtained when the mean spiral angle is substituted for the nominal helix angle in Eq. (1b).

\subsection{Virtual Gear Ratio}

Bevel gear meshing must be considered in pairs because the pitch cone angles are restricted by the gear ratio. In conventional configuration of bevel gearsets, the shaft angle is:

$$
\varphi_{0}=\varphi_{1}+\varphi_{2}
$$

Generally, shaft angles between $30^{\circ}$ and $150^{\circ}$ are usually permissible subject to certain ratio limitations as indicated in Eqs. (8) and (9). It should be noted that some gear generators require pinion pitch angle above $5^{\circ}[40]$.

When $\varphi_{o} \leq 90^{\circ}$, the cone pitch angles are obtained as [22]:

$$
\tan \varphi_{1}=\frac{\sin \varphi_{1}}{\mu+\cos \varphi_{0}} \tan \varphi_{2}=\frac{\mu \sin \varphi_{0}}{1+\mu \cos \varphi_{0}}
$$

When $90^{\circ}<\varphi_{0}<180^{\circ}$, then [23]: 


$$
\begin{aligned}
\tan \varphi_{1} & =\frac{\sin \left(180^{\circ}-\varphi_{0}\right)}{\mu+\cos \left(180^{\circ}-\varphi_{0}\right)} \\
\tan \varphi_{2} & =\frac{\mu \sin \left(180^{\circ}-\varphi_{0}\right)}{1+\mu \cos \left(180^{\circ}-\varphi_{0}\right)}
\end{aligned}
$$

The virtual or equivalent gear ratio of a helical bevel gearset based on Eq. (6) is:

$$
\mu_{v}=\frac{d_{v 2}}{d_{v 1}}=\mu \frac{\cos \varphi_{1}}{\cos \varphi_{2}}
$$

\subsection{Virtual Contact Ratio}

The number of teeth on the gearset based on Tredgold's approximation is:

$$
z_{v 1}=\frac{z_{1}}{\cos \varphi_{1} \cos ^{3} \psi_{b}} \quad z_{v 2}=\frac{z_{2}}{\cos \varphi_{2} \cos ^{3} \psi_{b}}
$$

The contact ratio on the virtual plane is:

$$
\varpi_{v}=\frac{k_{1}+k_{2}}{\pi \cos \phi_{n}}
$$

where:

$$
\begin{aligned}
& k_{1}=0.5\left(\sqrt{\left(z_{v 1}+2\right)^{2}-\left(z_{v 1} \cos \phi_{n}\right)^{2}}-z_{v 1} \sin \phi_{n}\right) \\
& k_{2}=0.5\left(\sqrt{\left(z_{v 2}+2\right)^{2}-\left(z_{v 2} \cos \phi_{n}\right)^{2}}-z_{v 2} \sin \phi_{n}\right)
\end{aligned}
$$

The contact ratio, $\varpi_{v}$ is indicative of the proportions of the gear teeth in a mesh that share the transmitted load.

Please note that equations (6) to (13) do not apply to bevel crown gears where $\varphi_{2}=90^{\circ}$.

\section{CONTACT STRESS ESTIMATE}

During meshing, contact occurs in an involute gear mesh on two convex surfaces. The contact point would trace out a line if the gear materials and supporting structures were infinitely rigid. Due to material elasticity, the gear teeth deform slightly to form a rectangular contact patch. A gear pair in mesh is analogous to that of a pair of two cylinders of some equivalent diameters, rolling without slipping [10]. Buckingham and his coworkers were the first researchers to investigate surface stresses in gear teeth in a systematic way [9] and they modified the Hertz contact stress expressions for two frictionless cylinders in contact to study gear pitting resistance. They defined the equivalent radii of curvature of the two gears in a mesh as the products of the pitch radii of the gearset and the sine of the gear pressure angle. In helical gears, contact occurs on the virtual plane; therefore, the contact force and design geometric parameters should be referred to the virtual plane, so it may be expressed as [19]:

$$
\sigma_{H}=\sqrt{\frac{F_{c} E_{c} \times 10^{3}}{\pi \rho_{v} b_{v} \varpi_{v}}}
$$

The composite elastic modulus is obtained as [19]:

$$
E_{c}=\frac{2 E_{1} E_{2}}{E_{1}\left(1-v_{2}^{2}\right)+E_{2}\left(1-v_{1}^{2}\right)}
$$

The effective instantaneous radius of curvature in the virtual plane during contact at the pitch point is [19]:

$$
\rho_{v}=\frac{2 r_{v 2} r_{v 1} \sin \phi_{n}}{r_{v 2} \pm r_{v 1}}
$$

Combining Eqs. (7) and (16):

$$
\rho_{v}=\frac{d_{e 2} \sin \phi_{n} \cos \psi}{\left(\mu_{v} \pm 1\right) \cos ^{2} \psi_{b} \cos \varphi_{2}}
$$

Due to the curvature of the teeth form of spiral bevel gears, actual contact is along an arc and this introduces an added complexity compared to cylindrical helical gears which have constant helix angle. The lengthwise curvature of spiral bevel gears gives the teeth a con-siderable amount of overlap, providing increased face contact ratio, tooth rigidity and adjustability to load induced deflection [25]. This makes the gears transmit motion more smoothly and quietly than straight bevel gears and the load is better distributed over more tooth surface [2]. Based on the mean spiral or helix angle, the face contact length may be approximated as:

$$
b_{v}=\frac{b_{e}}{\cos \psi_{b}} \approx \frac{b_{e}}{\cos \psi}
$$

Eq. (18) is accurate only for skew bevel gears but conservative for the curved teeth of zerol, and spiral bevel gear types. By using a mean spiral angle, a straight helical profile is assumed which reduces the actual arc of contact to a straight line whose length is shorter than the arc length. Hence the approximation in Eq. (18), upsets to some degree, the conservative estimate by a line contact.

Substituting Eqs. (A6), (17) and (18) into Eq. (14), yields:

$$
\begin{aligned}
& \sigma_{H}=\cos \psi_{b} \times 10^{3} \sqrt{\frac{2 K_{g} K_{b}\left(\mu_{v} \pm 1\right) E_{c} T_{1} \cos \varphi_{2}}{\varpi_{v} d_{e} d_{e 1} d_{e 2} \cos \psi}} \\
& K_{g}=\frac{2}{\pi \sin 2 \phi_{n}}
\end{aligned}
$$

Eq. (19a) is the theoretical contact stress capacity model of a helical bevel gear based on its spur gear equivalency. It reflects the principal design parameters that determine the Hertz contact stress and explicitly shows the influence of the nominal helix angle and the base helix angle on the contact stress capacity of helical bevel gears. Higher base helix angles lead to lower contact stresses, so helical gears would have higher load capacity than straight bevel gears of the same size.

Now, mathematical models are rarely if ever, able to depict exactly any physical system due to simplifying assumptions incorporated. They are, therefore, approximations and experiments are required in engineering to validate the models. Consequently, the theoretical model of Eq. (19a) needs adjustment for a) service load influence factors, b) gear tooth profile modification, and 
c) effective contact width. When these factors are incorporated into Eq. (19a), the engineering contact stress capacity model for helical bevel gears may be rendered as:

$$
\sigma_{H}=\cos \psi_{b} \times 10^{3} \sqrt{\frac{2 K_{s} K_{g} K_{x} K_{b}\left(\mu_{v} \pm 1\right) T_{1} E_{c} \cos \phi_{2}}{\lambda_{e} b d_{e 1} d_{e 2} \varpi_{v} \cos \psi}}
$$

Eq. (20) is the generalized expression for the contact stress estimate of helical bevel gears with accommodations for tooth profile modifications and service load adjustment. Eq. (20) can be applied for straight bevel gears by setting the nominal and base helix angles to zero. However, it is not applicable to crown gears for which $\varphi_{2}=90^{\circ}$.

The service load factor [19] encapsulates several load modification factors and takes care of load excitations beyond the rated value that are reoccurring in nature, not the peak load which occurs only occasionally. It is estimated as shown in Eq. (21).

$$
K_{s}=K_{a} K_{v} K_{m} K_{r} K_{p} K_{f}
$$

The load modification factors $K_{a}, K_{v}, K_{m}$, and $K_{r}$ are as defined in AGMA standards with similar but not necessarily identical equivalents in ISO standards. They are evaluated using AGMA methods which are somewhat simpler than those of ISO. Load modification factor $K_{p}$ [27] accounts for the influence of addendum modification or center distance adjustment on the load capacity of gears. It is a geometric parameter and is included in the service load factor because it affects both contact and bending stresses. Load modification factor $K_{f}$ [28] accommodates additional load due to the presence of mesh friction. Please refer to Appendix B: Service Load Factor Estimate for more information.

\subsection{Contact Stress Crowning Factor}

The teeth of most bevel gears are crowned in the axial direction during manufacturing to accommodate deflection of mountings [29, 30]. According to Norton [9], crowning makes the contact patch more elliptical than rectangular and produces increased localized contact stresses. The study of Gurumani and Shanmugan [31] on crowning of spur gears shows that the contact stress for elliptical contact patches is higher than that for line contact which produces a rectangular contact patch. The contact patch in bevel gears is an elongated ellipse [32] which suggests higher contact stress is likely. The increase in contact stress due to crowning is captured by the crowning factor $K_{x}$ in Eq. (20). Norton [9], Collins et al. [15] and Budynas and Nissbett [30] give a value of 1.0 for uncrowned teeth and 1.5 for crowned straight bevel gears. ANSI/AGMA 2003-A86 [33] and KISSsoft [34] recommend a crowning factor of 1.5 for an optimized spiral bevel gear, otherwise it is 2.0 or higher. According to Schmid et al. [35, p.435]; a crowning factor of 1.5 is appropriate for properly crowned spiral bevel teeth. Thamos [36] uses a value of 1.5 as the lengthwise crowning factor for ISO bevel gear model. Therefore, there appears to be a general agreement that
$K_{x}=1.5$ is acceptable for properly crowned bevel gears in both AGMA and ISO bevel gear standards and is adopted in this study. For uncrowned bevel gears, $K_{x}=$ 1.5.

\subsection{Effective Facewidth Factor}

Manufacturing and installation deficiencies combined with deflection under loads prevent gears from mating over the whole tooth width. Therefore, only a fraction of the nominal tooth width makes actual contact, which affects load sharing among the teeth in a mesh. The effective facewidth of a gear in contact during transmission may be expressed as:

$$
b_{e}=\lambda_{e} b \quad b=\min \left(b_{1}, b_{2}\right)
$$

The expected range of values for $\lambda_{e}$ is 0.80 to 0.90 for bevel gears [37, 38]. The approximation of the arc of face contact for helical bevel gears with a straight line (see Eq. (17)), makes the facewidth contact length estimate conservative. Hence an overly conservative value of the effective facewidth factor may not be necessary. Therefore, $\lambda_{e}=0.9$ is adopted for helical bevel gears in this study.

\section{ACCEPTABLE DESIGN}

Acceptability of a design is usually assessed by the value of a design or safety factor. For contact stresses, the estimated (apparent) contact stress design factor should be at least equal to the allowable minimum design factor. That is:

$$
n_{H}=\frac{S_{c}}{\sigma_{H}} \quad n_{H} \geq n_{c}
$$

The pitting load limit is defined as the maximum load that gives $1 \%$ pitting of the contact area on a gear pair for $10^{7}$ load cycles [2, p. 3.8]. The pitting strength is the contact stress produced by the pitting limit load and is improved by increasing the surface hardness and surface finish of the gearset. The nominal pitting strength is adjusted with conditional modification factors to obtain $S_{c}$. Note that $S_{c}$ is the same as is used for cylindrical (spur and helical) gears and can be obtained using AGMA methods. The parameter $n_{c}$ is a minimum number that may be prescribed by standards, codes or agreed on with a client. Generally, it is in the range of 1.0 to 1.3 , but preferably greater than unity.

\section{APPLICATION EXAMPLES}

In this section, the contact stresses of three design cases taken from [8, 24, 35], are estimated using the new model described above. The problem statements in the application examples have been paraphrased and the design parameters have been converted to metric units where necessary by the authors.

\section{Example 1}

A right-angle spiral bevel gearset with crowned teeth made of steel transmits $0.9 \mathrm{~kW}$ with the pinion running 
at $14,000 \mathrm{rpm}$. The pinion has 15 teeth and is cantilever mounted while the gear has 32 teeth and is straddle mounted. The gearset has a transverse module of 1.5 $\mathrm{mm}$, facewidth of $8.84 \mathrm{~mm}$ and made to ISO quality number 9. The load application factor may be assumed as 1.5 [8, p. $431-435]$. What is the expected contact stress in the mesh if the helix angle is $35^{\circ}$ ?

\section{Example 2}

A right-angle spiral bevel gearset with crowned teeth made of steel transmits $10.25 \mathrm{~kW}$ with the pinion running at $1450 \mathrm{rpm}$. The pinion has 13 teeth and is cantilever mounted while the gear has 42 teeth and is straddle mounted. The gearset has a transverse module of $4.29 \mathrm{~mm}$, facewidth of $26 \mathrm{~mm}$. [24, p. 298 - 303]. What is the expected contact stress in the mesh if the helix angle is $35^{\circ}$ ?

\section{Example 3}

A right-angle spiral bevel gearset with crowned teeth made of steel transmits $30 \mathrm{~kW}$ with the pinion running at $1750 \mathrm{rpm}$. The pinion has 14 teeth and is cantilever mounted while the gear has 40 teeth and is straddle mounted. The gearset has a transverse module of 4.45 $\mathrm{mm}$, facewidth of $25.4 \mathrm{~mm}$ and made to ISO quality number 6 . The load application factor may be assumed as 1.0 [35, p. $434-435]$. What is the expected contact stress in the mesh if the helix angle is $25^{\circ}$ ?

\subsection{Solutions}

Three gear standards are used in estimating the contact stresses in the application examples considered above. These standards are labeled A, B, and C. Gear standard $\mathrm{A}$ is that of helical cylindrical gears where the addendum radius is obtained by adding one normal module to the pitch radius. Therefore, this standard uses an addendum factor of 1.0. Gear standard A is used by ISO, AGMA, JIS (Japanese Industrial Standards] and other national standards for cylindrical gears. It is also the ISO standard for straight bevel gears. Gear standards $\mathrm{B}$ and $\mathrm{C}$ are based on Gleason bevel gear system which is essentially a stub gear standard. Gear standard B uses a constant addendum factor of 0.85 , while gear standard $\mathrm{C}$ uses a variable or custom addendum factor that is related to the virtual gear ratio (Eq. (10)) [4]. The addendum factor is applied at the backend diametral plane of the bevel gear for standards B and C. Previous solutions for examples 1 and 3 are based on AGMA bevel gear standards and that of example 2 is based on a defunct USSR (Union of Soviet Socialist Republic) GOST standard.

The formulas for contact stress estimates for the new models were coded into Microsoft Excel. This allows easy computational changes to be made in design parameters. Table 1 summarizes the basic gearset and load data for the design cases. Table 2 shows the contact stress values estimated using the current model and the previous solutions. The contact stress values in row 2 of Table 2 are those based on gear standard A, row 3 values are based on gear standard $B$, and row 4 values are based on gear standard C. The last row of Table 2 show the contact stress values of the previous solutions.
Table 3 shows the percentage variances between the current model solutions and the previous solutions.

Table 1: Input Parameters for Design Cases

\begin{tabular}{|l|c|c|c|}
\hline \multicolumn{1}{|c|}{ Parameter } & $\begin{array}{c}\text { Example } \\
\mathbf{1}\end{array}$ & $\begin{array}{c}\text { Example } \\
\mathbf{2}\end{array}$ & $\begin{array}{c}\text { Example } \\
\mathbf{3}\end{array}$ \\
\hline Input Power (kW) & 0.9 & 10.25 & 30 \\
\hline Input speed (rpm) & 14000 & 1450 & 1750 \\
\hline Output speed (rpm) & 6562.5 & 448 & 612.5 \\
\hline Pressure angle (deg.) & 20 & 20 & 20 \\
\hline Helix angle (deg.) & 35 & 35 & 25 \\
\hline Shaft angle (deg.) & 90 & 90 & 90 \\
\hline Normal module (mm) & 1.23 & 3.51 & 4.11 \\
\hline Pinion teeth number & 15 & 13 & 14 \\
\hline Gear teeth number & 32 & 42 & 40 \\
\hline Gear face width (mm) & 8.84 & 26 & 25.4 \\
\hline $\begin{array}{l}\text { Pinion face width } \\
\text { (mm) }\end{array}$ & 8.84 & 26 & 25.4 \\
\hline $\begin{array}{l}\text { Pinion pitch diameter } \\
\text { (mm) }\end{array}$ & 22.5 & 55.7 & 63.5 \\
\hline $\begin{array}{l}\text { Gear pitch diameter } \\
\text { (mm) }\end{array}$ & 48.0 & 180.0 & 181.4 \\
\hline Service load factor & 2.448 & 1.306 & 1.197 \\
\hline
\end{tabular}

Table 2: Contact Stress Estimates in MPa

\begin{tabular}{|c|c|c|c|}
\hline $\begin{array}{c}\text { Gear } \\
\text { Standard }\end{array}$ & Example 1 & Example 2 & Example 3 \\
\hline A & 410.0 & 708.0 & 983.0 \\
\hline B & 404.0 & 696.0 & 1012.4 \\
\hline C & 413.7 & 722.9 & 1049.7 \\
\hline $\begin{array}{l}\text { Previous } \\
\text { solution }\end{array}$ & 422.9 & 763.0 & 1103.2 \\
\hline
\end{tabular}

Table 3: Contact Stress Deviations (\%)

\begin{tabular}{|c|c|c|c|}
\hline $\begin{array}{c}\text { Gear } \\
\text { Standard }\end{array}$ & Example 1 & Example 2 & Example 3 \\
\hline A & -3.05 & -7.21 & -10.90 \\
\hline B & -4.46 & -8.78 & -8.23 \\
\hline C & -2.17 & -5.25 & -4.85 \\
\hline
\end{tabular}

\section{DISCUSSIONS}

Current international and national bevel gear design standards share three fundamental concepts of Hertz contact stress, spur gear equivalency based on Tredgold's geometric approximation and contact load and contact strength influence modification factors. The Tredgold's approximation of a bevel gear is near universal acceptance. It allows bevel gears to be designed with the geometric parameters defined at the backend of the bevel gear. However, differences exist in the application of Tredgold's approximation. For instance, AGMA 2003-B97 [16] applies the Tredgold's approximation at the backend plane of the bevel gear while ISO applies it at the mid-facewidth plane. Modification factors are separately applied to the contact load (stress) and contact strength in these standards. The modification factors are based on similar gear design philosophies and procedures, but the evaluation of specific parameters in the load and strength factors varies in the standards. These three fundamental concepts are assumed and applied in the current helical gear contact stress model. 
The current model differs from AGMA and ISO models by referring the gear forces to the backend of the bevel gear through the bevel load factor $\left(K_{b}\right)$ in Eq. (20). This means the forces acting at the backend are the same as those at the mid-width of the gear tooth. This allows the Tredgold's approximation and the transmitted load to be applied on the same plane, ensuring consistency of design analysis for bevel gears. Please refer to Eq. (A2) and Eq. (A5) in Appendix A, for a proof of the transmitted load transfer from the midfacewidth to the backend of the bevel gear.

The contact plane is based on the base helix angle in the new model, not on the nominal helix angle which is used in current standards of AGMA, but is incorporated in the zone factor parameter of ISO standards and JIS. The pitch radius of the virtual spur gear is smaller because it is based on the base helix angle which is always smaller than the nominal helix angle. This represents a major difference between the current models and existing gear standards.

In the current model, the virtual number of gear teeth is estimated using the base-helix angle, not the nominal helix angle used by current standards. Since the base helix angle is slightly smaller than the nominal helix angle, fewer numbers of virtual teeth are obtained for the bevi-spur gear in the current model. At low values of the nominal helix angles, there is not much difference between the virtual number of teeth obtained using the nominal or base helix angle, but at high nominal helix angles, the difference can become more relevant. At very high nominal helix angle, the difference in the number of virtual teeth from the two angles can become significant. In spiral bevel gears, the nominal helix angle can be high. Now, the virtual number of gear teeth has influence on the virtual contact ratio, which affects load sharing and the contact stress. Higher number of virtual teeth gives higher contact ratio, which leads to lower contact stress in Eq. (20). Therefore, the virtual contact ratio of a gearset based on the base helix angle will predict higher contact stress than those based on the nominal helix angle.

In bevel gears, the diametral pitch is conveniently measured at the backend of the tooth, while both the pressure angle and spiral angle are measured at mid-face on the tooth [40]. Since the mean spiral angle and pressure angle are measure on the same plane, it is logical to assume the mean spiral angle as the nominal helix angle. Eq. (19b) captures the role of the gear pressure angle in determining the magnitude of the contact stress through the gear contact stress form factor. This factor is simpler than the zone factor in ISO and JIS standards, being a function of only the pressure angle. It has a direct influence on contact stress, and thus may be used to compare the influence of pressure angle on contact stress by different gear systems.

Fig. 4 shows a plot of the gear contact stress form factor. As can be seen in Fig. 4, pressure angles above $20^{\circ}$ have a value lower than unity and continue to decrease till about $45^{\circ}$. Beyond $45^{\circ}$, its value begins to increase. Therefore, designing gears with pressure angle above $45^{\circ}$ appears not be to be beneficial. From Fig. 4, pressure angles may be differentiated into two categories: low and high values. Pressure angle less than $20^{\circ}$ may be considered low and those between $20^{\circ}$ and $45^{\circ}$ may be considered high.

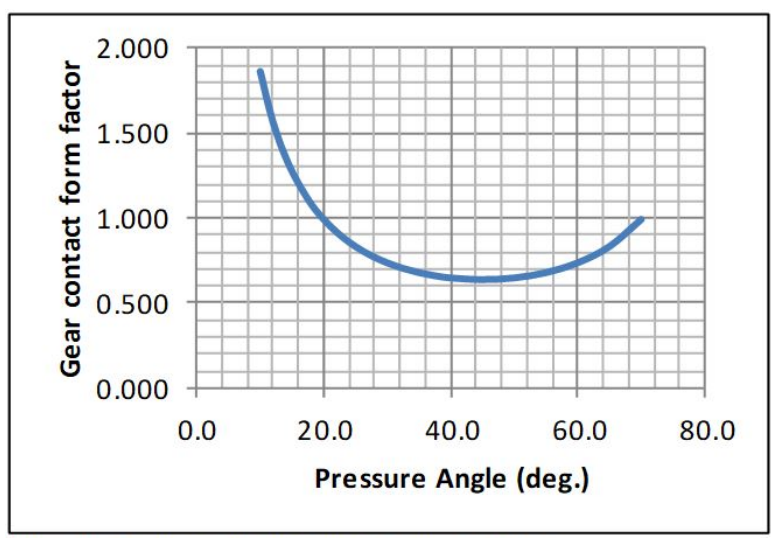

Fig. 4: Gear contact stress form factor

Eq. (20) is the expression for the contact stress of helical bevel gears which are considered similar to cylindrical helical gears having a nominal helix angle equal to the mean spiral angle for helical bevel gears. It does not require any chart for application and most of the parameters in the expression can be easily estimated. For instance, most of the components of the service load factor (Eq. (21)), in the new model are the same as in AGMA standards and are estimated using AGMA methods. The load application factor component is generally selected from appropriate tables in AGMA, JIS, and ISO gear standards. The non-AGMA component parameters in the service load factor are estimated using expressions provided elsewhere [27, 28].

It should be noted that AGMA bevel contact stress model has a size factor which is not incorporated in the current model. The size factor is often applied to the nominal strength instead of the expected stress. For instance, AGMA applies a size factor to the nominal beam strength in cylindrical gears. In the current model, the size factor is assumed applied to the nominal contact strength. Therefore, the same nominal contact strength of gear materials can then be used for both cylindrical and bevel gear types with appropriate size factors.

The current model differs conceptually from AGMA spiral bevel standards which treat the helical bevel gears as spur gear rather than a helical gear as indicated in Eq. (2b). This implies that the module of helical bevel gear may be selected based on the normal module as in helical cylindrical gears. Consequently, both cylindrical and bevel gears can be treated on a consistent basis. Also, this should allow smaller module to be used to achieve the same backend pitch diameter as it is done in current cylindrical helical gear standards. Smaller module size reduces manufacturing cost and enhances cutting tooth strength because lesser material is removed during machining operations, which lowers deformation during cutting operations, and hence increases manufacturing accuracy [39, p. 283].

Eq. (20) may be used for cylindrical helical gears by setting the bevel gear pitch angles to zero degree and the bevel load factor to unity. For spur gears it is necessary to additionally set the nominal and base helix angles to zero degree. However, for cylindrical gears, the effecttive facewidth factor $\lambda_{e}$ is set to 0.95 instead of 0.90 in bevel gears. Therefore, for cylindrical gears: 


$$
\sigma_{H}=\cos \psi_{b} \times 10^{3} \sqrt{\frac{2 K_{s} K_{g} K_{x}\left(\mu_{v} \pm 1\right) T_{1} E_{c}}{\lambda_{e} b d_{1} d_{2} \varpi_{v} \cos \psi}}
$$

The virtual contact ratio $\varpi_{v}$ for cylindrical gears is now based on the virtual number of teeth on the pinion and gear which is then obtained from Eq. (5). The crowning factor $K_{x}$ in cylindrical gears does not need to be 1.5 , but standard value(s) seem to be lacking at this time. The difference between Eq. (24) and that in [19] for cylindrical gears is that the latter can be interpreted as an approximation of the former. This is because in the cited reference an approximation is made in the estimation of $\varpi_{v}$, but no such approximation is made in Eqs. (12) and (13) here.

An unsolved problem in gear design modeling is how to realistically or practically combine transverse contact ratio with axial contact ratio when the latter is greater than unity in helical gears. It is known that axial contact ratio greater than unity improves load sharing and reduction in noise during operation. In fact, for maximum smoothness of drive, the face contact ratio should be between 1.5 and 2.0 and high speed applications should be designed with a face contact ratio of 2 or higher $[10,11]$ for spiral bevel gears. However, there is currently no definitive method of combining axial contact ratio greater than unity with the transverse contact ratio when estimating gear stresses. Therefore, Eqs. (20) and (24) make use of only the virtual transverse contact ratio of Eq. (12). If axial contact ratio greater than unity is properly incorporated in Eqs. (20) and (24), the estimated stress values will be lower.

The contact stresses obtained using Eq. (20) for three application examples are shown in Table 2 and comparisons with the previous solutions are presented in Table 3. From Table 2, solutions based on gear standard A appear to be the least conservative compared to the previous solutions. The most conservative results are from gear standard C, while those of standard B are between the results for standards $\mathrm{A}$ and $\mathrm{C}$.

In Table 3, the variances between the contact stress estimates from the new helical gear contact stress model and the AGMA/GOST standards are in the range of $-3 \%$ to $-11 \%$. These variances are negative because the estimated contact stresses from the new model are lower than the previous solutions. Though the differences appear to be small, they can be quite significant, because the durability service life of gears is strongly dependent on contact stress. For instance, Feng and Song [13] found that a $4.76 \%$ decrease in the contact stress of a steel spiral bevel gearset increased the pitting service life by $44 \%$. Consequently, there is a need to determine the maximum contact stress in gear meshes with reasonable accuracy because a small decrease in contact stress can significantly increase the pitting service life of a gearset. Similarly, a small increase in contact stress can dramatically reduce the pitting service life of a gearset.

\section{CONCLUSIONS}

A contact stress expression (Eq. (20)) for helical bevel gears is derived based on several simplifying but realistic assumptions. These assumptions include transmitted load acting at the gear mid-facewidth plane, nominal helix angle equal to the value at mid-facewidth plane of helical bevel gears, spur gear equivalency of helical gear in base helix angle plane, and the Tredgold's approximation of bevel gears. The assumptions of the transmitted load being at the midplane of gear facewidth and straight helix angles are conservative. The assumption of spur gear equivalency of helical gear on the base helix plane is more accurate than that at the normal plane defined by the nominal helix angle [10]. The base helix plane essentially defines the plane of the contact force on which a more accurate analysis can be based. The Tredgold's approximation assumption of spur gear equivalency of bevel gear in transverse plane is approximate. It provides a geometric link between a physical bevel gear and the equivalent or virtual spur gear. The assumption of forces acting on the mid-facewidth of the physical bevel gear allows for the definition of a bevel load factor which transfers the forces to the Tredgold's spur gear defined at the backend plane of the bevel gear. The bevel load factor, therefore, provides a kinetic link between a physical bevel gear and the virtual spur gear. The expression of Eq. (20) was easily modified for helical cylindrical gears, which is given by Eq. (24).

Eq. (20) is applied in estimating the contact stress in three gear systems with three application examples and compared with previous solutions based on AGMA/GOST standards. The contact stresses obtained are shown in Table 2 and comparisons with the previous solutions are shown in Table 3. Differences in estimated results vary between $-3 \%$ and $-11 \%$, with the new model estimates consistently being marginally or slightly lower than the previous solution values. Though the differences appear to be small, however, they are significant because the durability of gears is strongly influenced by the contact stress. For example, a 5\% reduction in contact stress may result in almost 50\% increase in durability, which underscores the need for a more accurate estimate of contact stresses. The differences in the contact stress value estimates may be attributed to the difference in the application of the Tredgold's geometric approximation and the use of the base helix angle in this study.

The variances in Table 3 indicate that the new model developed predicts contact stress values that are less conservative than AGMA or GOST values. Though more design examples and comparisons are necessary for further verification, the results presented provide some encouragements. ISO 10300 [37] examples are not considered in this presentation but previous studies [27, 29] suggest that some ISO 10300 model contact stress estimates can be more conservative than AGMA model values, especially when loads are high.

\section{ACKNOWLEDGEMENTS}

The authors gratefully acknowledge that this study was supported with facilities at Texas Southern University and in parts with funds from COSET Research Fund and the University Faculty Development Fund of Texas Southern University, Houston, Texas. 


\section{APPENDIX A: BEVEL GEAR LOADS}

In the design analysis of bevel gears, the load is commonly assumed to be applied at the mid-facewidth plane. The resultant forces actually act somewhere between the midpoint and the backend of the tooth width [10]. This means the force components used in design analysis are slightly over-rated. It should be noted that the complexities of the tooth profile of bevel gears make precise analysis rather very complicated and such a conservative approach is justified. Fig. A1 shows the forces that are generated at the mid-width pitch circle of a bevel gear. Fig. A2 is the axial plane of the helical bevel gear.

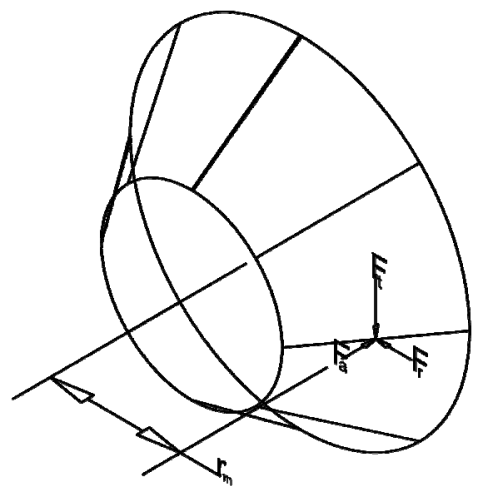

Fig. A1: Forces in bevel gear

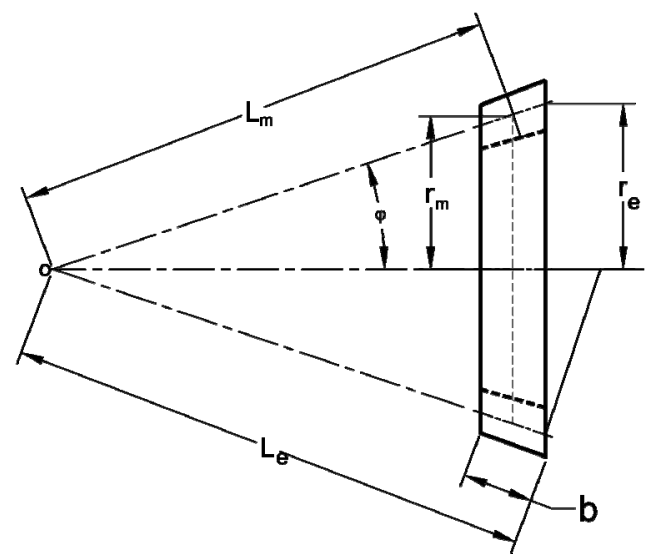

Fig. A2: Axial plane of bevel gear Gear

The torque load on the pinion is:

$$
T_{1}=\frac{30 P_{1} \times 10^{3}}{\pi N_{1}}
$$

The transmitted force is:

$$
F_{t}=\frac{T_{1} \times 10^{3}}{r_{m 1}}=\frac{T_{2} \times 10^{3}}{r_{m 2}}
$$

In bevel gears, the radial distance to a point on the cone from the shaft axis in the transverse plane is a linear function of the distance of that point from the apex of the cone. Therefore, by similar triangles in Fig. 2a:

$$
\frac{r_{m}}{r_{e}}=\frac{m}{m_{e}}=\frac{L_{m}}{L_{e}}
$$

Then:

$$
d_{m}=d_{e}\left(\frac{L_{m}}{L_{e}}\right)=\frac{d_{e}}{K_{b}} \quad K_{b}=\frac{L_{e}}{L_{m}}=\frac{L_{e}}{L_{e}-0.5 b}
$$

Substitute Eq. (A4a) in Eq. (A2):

$$
F_{t}=\frac{2 K_{b} T_{1} \times 10^{3}}{d_{e 1}}=\frac{2 K_{b} T_{2} \times 10^{3}}{d_{e 2}}
$$

Eqs. (A2) and (A5) provide the same estimate for the tangential force. This shows that the factor $K_{b}$ in Eq. (A5) effectively transfers the tangential force acting at the bevel gear mid-facewidth to the backend of the gear. This allows the Tredgold's approximation and the transmitted load to be applied on the same plane, providing consistency of design analysis for bevel gears.

The normal contact force is:

$$
F_{n}=\frac{F_{t}}{\cos \psi \cos \phi_{n}}
$$

The radial and axial forces in spiral bevel gear meshes are more complicated than for cylindrical helical gears. Both the helix hand and shaft rotation direction must be known to be able to correctly identify the magnitude and direction of axial forces. When viewing the gear from the large end; two cases: Case I and Case II may be distinguished.

Case I: Right-hand helix and CW rotation or Left-hand helix and $\mathrm{CW}$ rotation:

$$
\begin{aligned}
& F_{a}=F_{t}\left[\tan \phi_{t} \sin \varphi-\tan \psi \cos \varphi\right] \\
& F_{r}=F_{t}\left[\tan \phi_{t} \cos \varphi+\tan \psi \sin \varphi\right]
\end{aligned}
$$

Case II: Right-hand helix and CCW rotation or Lefthand helix and $\mathrm{CW}$ rotation:

$$
\begin{aligned}
& F_{a}=F_{t}\left[\tan \phi_{t} \sin \varphi+\tan \psi \cos \varphi\right] \\
& F_{r}=F_{t}\left[\tan \phi_{t} \cos \varphi-\tan \psi \sin \varphi\right]
\end{aligned}
$$

The equations above give the forces on the gear. The corresponding forces on the pinion are obtained by noting that the axial force on the gear is equal to the radial force on the pinion and radial force on the gear is equal to the axial force on the pinion. Helix hands should be chosen so that the axial points away from cone center for the pinion and the radial force of the gear presses down on the pinion to maintain contact.

\section{APPENDIX B: SERVICE LOAD FACTOR ESTIMATE}

The service load factor accounts for the fact that the forces acting on gear drive meshes in service are generally higher than the rated or nominal values. It is used to capture the combined influence of several load modification factors that can best the estimated experimentally and or are informed by experience. Human experience, knowledge and skills, test facilities and accuracy of test equipment are obvious factors that can ultimately affect the numerical values of some of these load modification factors. But good engineering practice and tireless efforts of innumerable researchers 
have resulted in values that are trustworthy. Therefore, realistic operating force values in gear meshes can be estimated with good confidence when the modification factors are used. The service load factor as defined here, does not account for short-time or momentary overload. It is only used to account for overloads that are of reoccurring nature during normal operating conditions. It is expressed as:

$$
K_{s}=K_{a} K_{v} K_{m} K_{r} K_{p} K_{f}
$$

\section{B1: Application (External Overload) Factor, Ka}

The external overload factor accounts for probable load variations arising from the accelerations and or decelerations of connected masses of power source equipment and the driven or load equipment. It is used to adjust the rated load value in order to accommodate overloads that are reoccurring in nature during normal operating conditions. It does not account for resonance induced overload which may occur if an excitation has a frequency near one of the geared system's natural frequencies. The external overload factor can only be established after considerable field experience in a particular field [38]. Many industries have established suitable values based on experience [41] and AGMA has recommended external overload for the design of gear reducers. The values of $K_{a}$ recommended by AGMA and ISO standards are basically the same.

\section{B2: Internal Dynamic Overload Factor, $\left(K_{v}\right)$}

The usual noise from rotating pairs of gears results from collision between gear teeth during operation. Such collisions raise the load on the gear more than the rated load and that increase is accounted for by the internal dynamic overload factor. The collisions are caused by non-conjugate meshing action of gear teeth during engagement, dynamic imbalance, and shaft misalignnment. Conjugate action is possible only if gear teeth have perfect involute geometry, hence manufacturing inaccuracy of any kind makes conjugate action impossible. Excitations from manufacturing inaccuracies are usually pronounced in spur gears without profile modification. Profile modified spur and regular helical gears (axial contact ratio more than unity) have lower excitations from theses inaccuracies. In addition to nonconjugate action, shaft misalignment and the relative speed between gear teeth when they come into contact lead to internal acceleration and deceleration of the gears and connected parts during tooth engagement. The internal dynamic overload factor is determined experimentally by loading a gearset of a designated quality number to failure at zero velocity and at a specified pitch line velocity. The ratio of the static failure load to the dynamic failure load is taken as the internal dynamic factor [41]. It is defined as:

$$
K_{v}=\frac{F_{t}+F_{d}}{F_{t}}=1+k_{v} \quad K_{v}=\frac{F_{d}}{F_{t}}
$$

AGMA [38] has developed approximate empirical expressions for the internal dynamic overload factor based on gear profile manufacturing quality and pitch velocity. AGMA gear profile manufacturing quality numbers range from 0 to 12 [42], and are similar to ISO quality numbers. In the numbering scheme, lower numbers represent higher gear profile manufacturing quality. Based on AGMA recommendations and for AGMA/ISO gear quality numbers in the range of $6 \leq q_{n} \leq 12$, a general internal dynamic load factor may be obtained using Eqs. (B3) and (B4).

$$
\begin{aligned}
& a_{1}=0.25\left(q_{n}-5\right)^{2 / 3} \quad a_{2}=3.5624+4\left(1-a_{1}\right) \\
& K_{v o}=\left[1+\frac{\sqrt{V_{t}}}{a_{2}}\right]^{a_{1}} \quad V_{t}=\frac{\pi d N}{60} \times 10^{3}
\end{aligned}
$$

Helical gears with at least unity axial contact ratio run more quietly than spur gears [30]. Spiral bevel gears generally exhibit lower noise and vibration level than spur gears in operation, allowing their applications for higher velocity than spur gears [24]. Maitra [10, p. 2.90] states that the dynamic load for helical gears can be taken as $75 \%$ that of spur gears. Since by definition (Eq. (B2)), the internal dynamic factor is at least unity, it was suggested that internal dynamic overload factor may be estimated using Eq. (B5a) for spur gears and Eq. (B5b) for helical gears [43].

$$
K_{v}=K_{v o} \quad K_{v}=1+0.75\left(K_{v o}-1\right)
$$

The maximum recommended pitch point velocity for a gear profile quality number is:

$$
V_{t \max }=0.005\left[14+a_{2}-q_{n}\right]^{2}
$$

It should be noted that higher pitch point velocity requires higher profile manufacturing quality number. For high-speed applications, especially those above 20 $\mathrm{m} / \mathrm{s}$, methods that account for gear material properties, mass and inertia of the gears, and actual tooth profile errors should be used to estimate $K_{v}$ [41].

\section{B3: Mesh Overload Factor, $\left(K_{m}\right)$}

The mesh overload factor takes care of non-uniform load distribution along the tooth contact length which is caused by misalignment of gears and shafts due to dynamic twisting and bending. This results from the rigidity of and clearances in gear supporting members (like bearings, shafts, and housing), manufacturing inaccuracy, tooth width and spacing, and geometric characteristics of gear tooth. Variation in contact stress occurs in both axial and radial directions of the gear mesh [2] and the problem becomes more pronounced with larger facewidth [9]. Accurate determination of the mesh overload factor is one of the most difficult tasks in gear design. The mesh overload factor is defined as the ratio of the maximum load intensity to the average load intensity. That is:

$$
K_{m}=\frac{q_{\max }}{q_{a}}=1+\frac{q_{i}}{q_{a}} \quad k_{m}=\frac{q_{i}}{q_{a}} \quad K_{m}=1+k_{m}
$$

For bevel gears, values of mesh overload factor are highly dependent on the mounting configuration of both pinion and gear. Preferred mounting configuration is for 
both gears to be straddle mounted, but this may not always be possible. Hence, one-straddled gear and onecantilevered gear configuration is common in practice. Both gears may be cantilevered but this is a rare configuration in practice and is not recommended. Based on AGMA standard 2003-A86 [33] and for crowned bevel gears of facewidth up to $356 \mathrm{~mm}$, a general mesh overload factor may be approximated by Eq. (B8) $[15,30]$. Experience indicates that helical gears are slightly less sensitive to mounting conditions [44, $\mathrm{p}$. 551] and AGMA allows a reduced value of spur gears mesh overload factor for helical cylindrical gears, therefore it was suggested [19,43] that Eq, (B9a) and Eq. (B9b) may be used for crowned straight bevel gear teeth and crowned helical bevel gear teeth, respectively.

$$
\begin{aligned}
& K_{m c}=K_{m o}+5.6 b^{2} \times 10^{-6} \\
& K_{m}=K_{m c} \quad K_{m}=1+0.85\left(K_{m c}-1\right)
\end{aligned}
$$

Table A1 gives suggested values of $K_{m o}$.

Table A1: Basic Mounting Factor [16, p667]

\begin{tabular}{|l|c|}
\hline \multicolumn{1}{|c|}{ Gear Mounting Type } & $\begin{array}{c}\text { Basic Mesh Overload } \\
\text { Factor }\left(K_{m o}\right)^{*}\end{array}$ \\
\hline Both gears straddled & 1.00 \\
\hline One gear straddled & 1.10 \\
\hline Both gears cantilevered & 1.25 \\
\hline *For crowned bevel gearsets only \\
\hline
\end{tabular}

AGMA is yet to provide specific guidance on the variation of contact stress in the radial direction. However, ISO 6336 defines what may be called a "radial mesh overload factor" and suggests a value of 1.1 for shaved teeth and 1.0 for ground teeth [45]. This factor seems negligible, especially for bevel gears used in high speed applications.

\section{B4: Rim Rigidity Factor, $\left(K_{r}\right)$}

The Lewis bending stress formula assumes a gear tooth attached to a perfectly rigid base support. This is true only if the gear rim is sufficiently rigid or thick enough. Large diameter gears of cast or fabricated construction having relatively thin rim are more flexible and may be subjected to low frequency vibration modes [46] that can cause gear failure. Traditionally, the rim rigidity factor is applied to the bending load only. Since during contact, the load on the tooth causes both bending and contact stresses at the same time, some authors believe the rim rigidity factor should apply to contact stress also $[27,29]$. Gear tooth base support rigidity is assessed by the rim backup ratio which is defined as the rim thickness divided by the whole depth of gear tooth. AGMA experimental data suggest that when the rim backup ratio is greater than 1.2 , the rim rigidity factor is unity, otherwise it is above unity. Based on AGMA [38] recommendation, the gear rim rigidity factor may be obtained from Eqs. (B10) and (B11).

$$
\lambda_{r}=\frac{t_{r}}{h_{t}} K_{r}=1.0 \text { for } \lambda_{r} \geq 1.2
$$

$$
K_{r}=1.6 \ln \left[\frac{2.242}{\lambda_{r}}\right] \text { for } 0.5 \leq \lambda_{r} \leq 1.2
$$

For standard ISO cylindrical and bevel gears, $h_{t}=$ $2.25 m_{t}$. A rim back up ratio of $\lambda_{r}=1.2$ suggests a rim thickness, $t_{r}$ of 2.70 times the gear transverse module for spur and straight bevel gears of ISO standard proportions. For a Gleason bevel gear system, the rim thickness, $t_{r}$ is about 2.63 times the gear transverse module.

\section{B5: Mesh Frictional Load factor}

It has been established that the presence of mesh friction slightly increases the load on gears [28]. Mesh friction describes the frictional behavior occurring on the surfaces of a pair of gears in contact during operation. Frictional traction can arise from an oil film viscosity or from metal-to-metal contact during the steady-state or transient-state operation of gearsets. Gear mesh friction is complicated with contributions from sliding and rolling motions. However, pure rolling motion occurs only in the vicinity of the pitch point and a mixture of sliding and rolling motions predominate elsewhere [30)]. Sliding friction is more significant in power loss than the rolling friction component. The frictional load factor for closed gear drives may be evaluated from Eq. (B12) [28].

$$
\begin{aligned}
& K_{f} \approx 1+\frac{0.10}{V_{s}^{0.25}} \leq 1.10 \\
& V_{s} \approx 5 V_{t}\left[\frac{1}{z_{1}}+\frac{1}{z_{2}}\right]
\end{aligned}
$$

Higher peripheral speed facilitates the formation of an oil wedge in the contact area, resulting in lower frictional losses, [5].

\section{B6: Profile Modification Factor, (Kp)}

The standard or basic tooth profile of involute gears defined by the pressure angle is accommodated in the mesh contact stress expression by the gear contact form factor defined in Eq. (19b) in the article. Sometimes, the basic tooth profile is modified by changing the proportion of the addendum. Also, the center distance of gearsets may be adjusted during assembly which could alter the standard pressure angle during service. When the addendum is modified or center distance is adjusted, the working pressure angle of the gearset may be different from the standard value. The influence of addendum modification or center distance adjustment on the load capacity of gears is captured by the parameter:

$$
K_{p}=\frac{\tan \phi_{t}}{\tan \phi_{w n}}
$$

\section{B6.1: Addendum Modified Gears}

The working pressure angle for addendum modified gearset is [Maitra (2014)]:

$$
\operatorname{inv} \phi_{w n}=i n v \phi_{t}+\frac{2 s_{x} \tan \phi_{n}}{z_{1}+z_{2}} \quad s_{x}=x_{n 1}+x_{n 2}
$$


Generally, $s_{x}$ may be zero or non-zero in value after a gearset addendum is modified. When $s_{x}$ is zero, the working pressure angle of the gearset is un-affected by profile modification. If $s_{\mathrm{x}}$ is non-zero and positive, the working pressure angle is increased and $K_{p}$ is less than unity so that the contact stress is reduced. If $s_{x}$ is nonzero and negative, the working pressure angle is decreased, $K_{p}$ is greater than unity, resulting in increased contact stress.

\section{B6.2: Center Distance Adjusted Gears}

Sometimes the center distance of a gearset may be adjusted for proper backlash or a preferred value may be prescribed for a design. The working center distance is then not the same as the standard value based on the pitch radii of the gears in the mesh. The working pressure angle is obtained as:

$$
\phi_{w n}=\cos ^{-1}\left[\frac{C_{s}}{C_{w}} \cos \phi_{n}\right]
$$

\section{NOMENCLATURE}

\begin{tabular}{|l|l|}
\hline 1 & subscript for pinion \\
\hline 2 & subscript for gear \\
\hline$a_{1}$ & AGMA velocity exponent \\
\hline$a_{2}$ & AGMA velocity coefficient \\
\hline$b$ & nominal facewidth of a gear (mm) \\
\hline$b_{e}$ & effective facewidth of gear (mm) \\
\hline$b_{n}$ & facewidth on normal plane (mm) \\
\hline$b_{v}$ & gear facewidth on virtual plane (mm) \\
\hline$C_{s}$ & standard center distance \\
\hline$C_{w}$ & working center distance \\
\hline$d$ & helical gear pitch diameter (mm) \\
\hline$d_{0}$ & nominal spur gear pitch diameter (mm) \\
\hline$d_{e}$ & bevel gear backend pitch diameter (mm) \\
\hline$d_{e}$ & backend pitch diameter of pinion or gear (mm) \\
\hline$d_{a}$ & backend addendum (outside) diameter (mm) \\
\hline$d_{f}$ & backend dedendum (root) diameter (mm) \\
\hline$d_{n}$ & pitch diameter of heli-spur gear in virtual plane \\
\hline$d_{v}$ & pitch diameter of bevi-spur gear (mm) \\
\hline$E$ & elastic modulus of pinion or gear material (GPa) \\
\hline$E_{c}$ & composite or effective elastic modulus $(\mathrm{GPa})$ \\
\hline$F_{a}$ & axial force (N) \\
\hline$F_{c}$ & normal contact force (N) \\
\hline$F_{d}$ & incremental internal dynamic load (N) \\
\hline$F_{t}$ & transmitted or tangential force (N) \\
\hline$F_{r}$ & radial force (N) \\
\hline$h_{t}$ & gear tooth whole depth (mm) \\
\hline$k_{1}$ & access path length factor \\
\hline$k_{2}$ & reccess path length factor \\
\hline$K_{a}$ & application or external overload factor \\
\hline$K_{b}$ & bevel load factor \\
\hline$K_{f}$ & frictional load factor \\
\hline$K_{g}$ & contact stress form factor \\
\hline$K_{m}$ & mounting or mesh overload factor \\
\hline$k_{m}$ & incremental specific load factor \\
\hline$K_{m c}$ & general mesh overload factor \\
\hline$K_{m o}$ & basic mounting or mesh overload factor \\
\hline$k_{v}$ & incremental internal dynamic factor \\
\hline$K_{v}$ & general internal dynamic overload factor \\
\hline
\end{tabular}

\begin{tabular}{|c|c|}
\hline$K_{v}$ & internal overload or dynamic factor \\
\hline$K_{r}$ & rim flexibility load factor \\
\hline$K_{p}$ & profile modification load factor \\
\hline$K_{s}$ & service load factor \\
\hline$K_{x}$ & tooth lengthwise crowning factor \\
\hline$L_{m}$ & mid facewidth cone distance (mm) \\
\hline$L_{e}$ & backend cone distance $(\mathrm{mm})$ \\
\hline$m$ & mid facewidth module (mm) \\
\hline$m_{e}$ & backend transverse module (mm) \\
\hline$m_{n}$ & normal module $(\mathrm{mm})$ \\
\hline$m_{t}$ & transverse module $(\mathrm{mm})$ \\
\hline$n_{c}$ & allowable contact stress design factor \\
\hline$n_{H}$ & apparent contact stress design factor \\
\hline$N_{1}$ & rotational speed of pinion or gear (rpm) \\
\hline$P_{1}$ & transmitted power by pinion or gear $(\mathrm{kW})$ \\
\hline$q_{a}$ & average specific load $(\mathrm{N} / \mathrm{mm})$ \\
\hline$q_{i}$ & incremental specific load $(\mathrm{N} / \mathrm{mm})$ \\
\hline$q_{\max }$ & maximum specific load $(\mathrm{N} / \mathrm{mm})$ \\
\hline$q_{n}$ & gear tooth profile manufacturing quality number \\
\hline$r_{e}$ & backend pitch radius of pinion or gear (mm) \\
\hline$r_{m}$ & $\begin{array}{l}\text { mid facewidth pitch radius of pinion or gear } \\
(\mathrm{mm})\end{array}$ \\
\hline$r_{v}$ & virtual pitch radius of pinion or gear $(\mathrm{mm})$ \\
\hline$S_{H}$ & allowable or design contact stress $(\mathrm{MPa})$ \\
\hline$S_{c}$ & adjusted or service contact strength $(\mathrm{MPa})$ \\
\hline $\mathrm{S}_{\mathrm{X}}$ & residual profile shift factor on normal plane \\
\hline$t_{r}$ & rim thickness $(\mathrm{mm})$ \\
\hline$T$ & transmitted torque $(\mathrm{Nm})$ \\
\hline$T_{1}$ & transmitted torque by pinion or gear $(\mathrm{Nm})$ \\
\hline$V_{t}$ & Pitch point tangential velocity $(\mathrm{m} / \mathrm{s})$ \\
\hline$V_{t \max }$ & maximum pitch point tangential velocity $(\mathrm{m} / \mathrm{s})$ \\
\hline $\mathrm{x}_{\mathrm{n}}$ & $\begin{array}{l}\text { addendum correction or profile shift factor on } \\
\text { normal plane }\end{array}$ \\
\hline$z$ & physical number of teeth on gear or pinion \\
\hline$z_{n}$ & virtual number of teeth for helical gear \\
\hline$z_{v}$ & $\begin{array}{l}\text { virtual number of gear teeth for helical bevel } \\
\text { gear }\end{array}$ \\
\hline$\lambda_{e}$ & effective facewidth factor \\
\hline$\mu$ & gear ratio \\
\hline$\mu_{v}$ & equivalent or virtual gear ratio \\
\hline$\phi_{n}$ & normal pressure angle (deg.) \\
\hline$\phi_{t}$ & transverse pressure angle (deg.) \\
\hline$\phi_{w t}$ & working transverse pressure angle (deg.) \\
\hline$\phi_{w n}$ & working normal plane pressure angle (deg) \\
\hline$\psi$ & nominal helix angle (deg.) \\
\hline$\psi_{b}$ & base helix angle (deg.) \\
\hline$\varphi$ & pitch angle of bevel gear (deg.) \\
\hline$\varphi_{0}$ & shaft angle (deg.) \\
\hline$\varphi_{1}$ & pitch angle of pinion (deg.) \\
\hline$\varphi_{2}$ & pitch angle of gear (deg.) \\
\hline$\rho_{v}$ & $\begin{array}{l}\text { instantaneous radius of curvature on virtual } \\
\text { plane at pitch point ( } \mathrm{mm} \text { ) }\end{array}$ \\
\hline$\varpi_{v}$ & contact ratio on virtual plane \\
\hline$v$ & Poisson's ratio of pinion or gear material \\
\hline$\vartheta_{m}$ & mesh friction coefficient \\
\hline$\lambda_{r}$ & rim backup ratio \\
\hline
\end{tabular}

\section{REFERENCES}

[1] Stadtfeld, H. J., The Basics of Spiral Bevel Gears, Gear Technology, pp. 31 -38, 2001. 
[2] Dudley, D. W., Handbook of Practical Gear Design, CRC Press, 2004.

[3] Walsh, R. A., Electromechanical Design Handbook, 3rd Edition, McGraw Hill, New York, 2000.

[4] George Michalec, Elements of Metric Gear Technology, http://qtcgears.com/tools/catalogs/PDF_Q420/Tech. pdf. (accessed April 25, 2021).

[5] Berezovsky, Y., Chernilevsky, D. \& Petrov, M., Machine Design, MIR Pub., Moscow, 1988.

[6] Brown, M. D., Design and Analysis of a Spiral Bevel Gear, M. Thesis, Rensselaer Polytechnic Institute, Hartford, Connecticut, USA, 2009.

[7] Bhandari, V. B., Design of Machine Elements, 3rd edition, McGraw-Hill, New Delhi, 2010.

[8] Childs, P. R. N., Bevel Gears, Mechanical Design Engineering Handbook, Butterworth Heinemann Elsevier, Boston, Chap. 10, 2014.

[9] Norton, R. L., Machine Design: An Integrated Approach, p. 770, 2nd. Edition, Prentice-Hall, Upper Saddle River, New Jersey, USA, 2000.

[10] Maitra, G. M., Fundamentals of Toothed Gearing: Handbook of Gear Design, 2nd Edition, McGraw Hill, New Delhi, 2013.

[11] Shigley and Mischke, (1996) Shigley, J. E. and Mischke, C. R., Standard Handbook of Machine Design, 2nd Edition, McGraw-Hill, 1996.

[12] Coy, J. J., Townsend, D. P., Zaretsky, D. E. V., Gearing, NASA Reference Report 1152, AVSCOM Technical Report 84-C- 15, 1985.

[13] Feng, Z. \& Song, C. (2017), Effects of Geometry Design Parameters on the Static Strength and Dynamics for Spiral Bevel Gear, International Journal of Rotating Machinery, ID6842938, https://doi.org10.1155/2017/9842938.

[14] Stadtfeld, H. J. (Aug. 2015), Gear Mathematics for Bevel and Hypoid Gears, Gear Technology, pp. 50 $-56$.

[15] Collins, J. A., Busby, H., Staab, G. H., Mechanical Design of Machine Elements and Machines: A Failure Prevention Perspective, 2nd Edition, John Wiley and Sons, New York, 2010.

[16] ANSI/AGMA 2003-B97, 2003, https://www.agma. org/standards/ansi-agma-2003-b97/, (accessed April 2, 2021).

[17] RoyMech: Gears- Gear Efficiency, www.roymech. co.uk/Useful_Tables/Drive/Gear_Efficiency.html, (Accessed August, 2020)

[18] Wirth, C and Höhn, B. R. and Braykoff, C., New Methods for the Calculation of the Load Capacity of Bevel and Hypoid, AGMA Technical Paper 12FTM15, American Gear Manufacturers Association, Alexandria, Virginia, USA, 2012. ISBN: 9781-61481-046-9.

[19] Osakue, E. E. and Anetor, L., Helical Gear Contact Fatigue Design by Spur Gear Equivalency, Int'l
Journal of Research in Engineering and Technology, Vol. 06, Issue 02, 2017.

[20] Abdoli, H. A., Finite Element Approach to Spur, Straight Bevel and Hypoid Gear Design, Research Report in Mechanics, University of Oslo, 2005.

[21] Shigley J. E. and Uicker, Jr, J. J., Theory of machines and mechanisms, McGraw-Hill, 1995. Khurmi and Gupta, (2015).

[22] Khurmi, R. S. \& Gupta, J. K., A Textbook of Machine Design, Eurasia Pub. House, New Delhi, 2015.

[23] ÖzbağcI, B., Effect of Spiral Angle on Stress Distribution in the Spiral Bevel Gears, MSc. (MEng.) Thesis, Dokuz Eylül University Graduate School of Natural and Applied Sciences, 2012.

[24] Chernilevsky, D., A Practical Course in Machine Design, MIR, Moscow, 1990. pp. 73, 298 - 303.

[25] Stadtfeld, H., Tribology Aspects in Angular Transmission Systems, Part VII, Gear Technology, 2011,

https://www.geartechnology.com/issues/0111x/stad tfeld.pdf, (accessed April 18, 2021).

[26] Osakue, E. E., Simplified Spur Gear Design, Proceedings of International Mechanical Engineering Congress and Exposition 2016 IMECE, Paper Number IMECE2016-65426, November 11-17, Phoenix Arizona, USA, 2016.

[27] Osakue \& Anetor, Osakue, E. E. and Anetor, L., Design of Straight Bevel Gear for Pitting Resistance, FME Transactions 46, Vol.2, pp. 194204; doi:10.5937/fmet1802194O, 2018.

[28] Edward E. Osakue, Anetor, L. and Harris, K., A Parametric Study of Frictional Load Influence in Spur Gear Bending Resistance, FME Transactions journal, (2020) 48, 294 - 306.

[29] Osakue and Anetor, Osakue, E. E. and Anetor, L., Comparing Contact Stress Estimates of Some Straight Bevel Gears with ISO 10300 Standards, Proceedings of International Mechanical Engineering Congress and Exposition 2016 IMECE, Paper Number IMECE2018-86573, November 9-15, Pittsburgh, Pennsylvania, USA, 2018.

[30] Budynas, Richard, Nisbett, Keith, Shigley's Mechanical Engineering Design, 9th Edition, McGraw Hill, 2010.

[31] Gurumani, R. and Shanmugam, S., Modeling and Contact Analysis of Crowned Spur Gear Teeth, Engineering Mechanics, Vol. 18, No. 1, pp. 65 - 78, 2011.

[32] Moldovean, G., Gavrila, C. Butuc, B., Fatigue Stress Calculation of Straight Bevel Gears Applied to a Photo Voltaic Tracking System, Annals of The Oradea University, Fascicle of Management and Technological Engineering ISSUE \#1, 2013, http://www.imtuoradea.ro/auo.fmte/, (accessed Feb.15, 2021).

[33] ANSI/AGMA 2003-A86, Bevel Gear Rating Using the New Standard - AGMA 2003-A86, www.chegg.com, (accessed August 20, 2020). 
[34] KISSsoft, Calculation Programs for Machine Design: Bevel gear rating along AGMA2003 in KISSsoft, http://www.kisssoft.ch/english/downloads/pdf/AG MA2003_Comments.pdf, 2007, (accessed Aug 20, 2020).

[35] Schmid, S. R., Hamrock, B. J. \& Jacobson. O., Fundamentals of Machine Elements, 3rd Edition, CRC Press, New York, 2014.

[36] Thamos, J. (2018), ISO Standardization of Bevel Gears: Overview and Ideas on Method " $A$ ”, ZG Hypoid Gmbh.

[37] DET NORSKE VERITAS, (2003), Calculation of Gear Rating for Marine Transmissions, Classification Notes, No. 41.2, 2003, https://rules.dnvgl.com/docs/pdf/DNV/cn/201205/CN41-2.pdf, (March 10, 2021).

[38] ANSI/AGMA 2005-D03, Design Manual for Bevel Gears, pp. 40 - 41,

[39] http://allaboutmetallurgy.com/wp/wp-content/uploads/2016/12/Design-Manual-for-Bevel-

[40] Gears.pdf, 2005. Accessed March 20, 2021).

[41] Dobrovolsky, p. 283 Dobrovolsky V., Zablonsky K., Mak S., Radchik A. and Erlikh L., Machine Elements, Moscow, 1965, p. 283.

[42] Crosher W. P., (2012), Bevel gears, pressure angles and their relationship, https:/gearsolutions.com /media/uploads/uploads/assets/PDF/Articles/Dec_1 2/1212_ToothTips.pdf. (Accessed May, 3, 2021).

[43] Mott, R. L. (2004), Machine Elements in Mechanical Design, 4th ed. SI, Pearson Prentice Hall.

[44] Lawson, E., New ANSI/AGMA Accuracy Standards for Gears -ANSI/AGMA 2015-1-A01; www.geartechnology.com/issues/0304/lawson.pdf.

[45] Edward E. Osakue and Anetor, L., Revised Lewis Bending Stress Capacity Model for Cylindrical Gears, The Open Mechanical Engineering Journal, 2020, Vol. 14, pp. 3 - 16.

[46] Juvinall, R. C., Marshek, K. M. (2017), Juvinall's Fundamentals of Machine Component Design, S.I. Version, Wiley, Singapore.
[47] McVittie, D., (1998), Calculating Spur and Helical Gear Capacity with ISO 6336, Gear Technology, pp. 11 - 14.

[48] Townsend, D., P., (1986), Common Problems and Pitfalls in Gear Design, NASA Technical Memorandum 88858, http://ntrs.nasa.gov/archive /nasa/casi.ntrs.nasa.gov/19870007600.pdf

\section{КОНТАКТНИ НАПОН КОД ХЕЛИКОИДНИХ КОНУСНИХ ЗУПЧАНИКА}

\section{Е.Е. Осакуе, Л. Анетор, К. Харис}

Хеликоидни конусни зупчаници имају нагнуте или закривљене зупце на конусној површини и најчешћи типови су коси, спирални, зерол и хипоидни конусни зупчаници. Због сложене геометрије конусних зупчаника, у пројектовању се највише користи концепт еквивалентних или виртуелних цилиндричних зупчаника. У раду се приступ базира на следећим претпоставкама: угао хеликоиде код хеликоидних конусних зупчаника једнак је средњем углу спирале, пречник корака на позадини је одређен као пречник хеликоидног зупчаника, примењена је Тредголдова апроксимација код хеликоидног зупчаника. На основу ових претпоставки интензитет контактног напона хеликоидних конусних зупчаника је формулисан преко три параметра дизајна. Нови модел интензитета контактног напона се користи за прорачун контактног напона код три система зупчаника на три примера и поређењем са претходним решењима. Разлике између нових прорачуна и вредности код претходних решења варирају од $-3 \%$ до $-11 \%$, при чему су нове процене доследне, али незнатно или нешто ниже од претходно добијених вредности. Иако су разлике наизглед мале, оне су од значаја јер контактни напон у великој мери утиче на трајност зупчаника. На пример, смањење контактног напона за 5\% може да повећа трајност неких челичних материјала за готово 50\%. Развијене једначине не односе се на конусне зупчанике са круном. 